\title{
EFFECT OF AMENDMENTS TO PETROLEUM AND NATURAL GAS LEASES*
}

\section{INTRODUCTION}

It is well known that in the oil and gas producing regions of Western Canada the majority of the petroleum and natural gas rights are owned by the Crown. However, a significant portion of these rights are privately owned by individuals and corporations, especially in the more populated regions. It is primarily these privately owned or sor-called freehold petroleum and natural gas rights with which this paper is concerned. Most of these freeholders' rights were made subject to petroleum and natural gas leases in the early and middle 1950's after the startling impact of the Leduc discovery in Alberta in 1947. These freehold petroleum and natural gas leases were granted usually for a term of ten years and so long thereafter as the substances under lease were produced. The practical and economic necessity of first exploring and developing the more favourable petroleum and natural gas regions resulted in many of these leases remaining undeveloped and unattended. Many of these early leases have in recent times proved to be inadequate because of various government regulations and judicial decisions which have restricted the applicability of certain provisions in these leases and also because of changing circumstances to which the lessee's interest must be adapted. Most of these leases have expired but others are still in existence. Some lessees who have paid substantial bonus considerations and who have made even more substantial investments in preliminary evaluation of the leased properties have found themselves handicapped by these regulations, decisions and changes in circumstances in commencing operations on the leased lands. Consequently, in most cases these leases have been amended to provide lessees with the needed relief to develop the lands. Common examples of amendments are pooling and unitization agreements which presumably have been executed to the mutual advantages of lessors and lessees. Both kinds of agreements usually, if not always, contain a provision that operations conducted on the pooled or unitized lands shall be deemed to be operations on the leased lands and such operations on or production from the pooled or unitized lands shall continue in force and effect each lease pooled or unitized although such operations or production may not be conducted upon or taken from the leased lands. Without such a provision the existing leases would expire by their own terms. The significance of unit agreements and their effect in prolonging leases becomes evident when one considers that, according to one writer, ${ }^{1}$ today in Alberta alone there are over 160 units, most of which have been formed since 1960, accounting for more than fifty percent of the Province's oil production and most of its production of natural gas.

- This paper was prepared by John F. Curran, of Pan American Petroleum Corporation, Calgary, Alberta. E. R. Grant of Marathon Oil Company, Calgary, collaborated in the research on "Pooling and Unitization Orders and Royalty Trust Agreements", infra at pages 292-301.

1 T. R. Denton, Oil and Gas Law for the General Practitioner-A Primer on Oil and Gas Law, "Unitization". A paper presented to the Alberta Branch of the Canadian Bar Assoclation, Alberta Branch at Calgary, February 26, 1965. 


\section{Top Lease and Option to Lease SubJect to Existing Petroleum and Natural Gas Lease}

Many companies in search of lands with favourable petroleum and natural gas prospects have succeeded in acquiring interests in lands already subject to existing leases. More than one lessee has been confronted with the necessity of amending an existing lease in order to pool or unitize the leased lands or for some other purpose, only to discover that during the currency of the existing lease the lessor had granted a second lease or potion to lease subject to the existing lease. This practice, although not prevalent in the industry, is commonly enough encountered and has raised vexing questions as to the effect of the second lease or option to lease on the rights of the lessor and original lessee to modify and amend the terms of an existing lease.

\section{The Potapchuk Case}

In Pan Ameican Petroleum Corporation and Fargo Oils Ltd. v. Minnie Potapchuk and Scurry-Rainbow Oils Limited ${ }^{2}$ the Trial Division of the Supreme Court of Alberta was squarely faced with the question of whether the parties to a petroleum and natural gas lease could amend a provision in the lease after the lessor had granted, during the currency of the existing lease, an option to lease which had been protected by a caveat before the amendment was made. In an action for a declaration that the existing petroleum and natural gas lease, as amended, was valid and subsisting and continued in force beyond its primary term, Mr. Justice Cairns held against the Plaintiffs and decided that under their option the Defendants had acquired an equitable contingent interest in the leased lands and that by registration of a caveat before the Plaintiff's lease was amended the Defendants' interest was protected from the date of registration from anyone else taking an interest, or improving or increasing any interest already held in derogation of the claim of the Defendants. The decision of the Trial Division was affirmed by the Appellate Division of the Supreme Court of Alberta. ${ }^{3}$ The Plaintiffs appealed to the Supreme Court of Canada but the decision of the Appellate Division of the Supreme Court of Alberta was unanimously affirmed."

Because the Potapchuk case stands as the only authority in Canada on the effect of an amendment of a provision in an existing petroleum and natural gas lease of lands which have become subject to an intervening caveated interest, it is necessary and useful to review the Potapchuk case in some detail.

The lease in question was granted for a primary term of 10 years from January 16, 1951. The lease was identical in all respects to the lease considered in the case of Shell Oil Company v. Gunderson. ${ }^{5}$ On May 10, 1956 the lessor granted to Minnie Potapchuk an option to lease the petroleum and natural gas in the lands then subject to Pan American's and Fargo's lease in the following terms:

The Optionor, being the beneficial owner of the petroleum, natural gas and all related hydrocarbons within, upon or under ... (160 acres) ... in consideration of the sum of ... Dollars paid to the Optionor by the Optionee (the receipt 2 (1964), 46 W.W.R. 237 (Alta. S.C.), aff'd (1965), 51 W.W.R. 700 (Alta. C.A.), aff'd (1965),

8 The decision of the Appellate Division of the Supreme Court of Alberta is set out in full at page 271 of this paper.

4 (1965), 51 W.W.R. 767.

[1960] S.C.R. 424 . 
whereof is hereby acknowledged) the Optionor DOTH HEREBY GRANT to the Optionee the sole and exclusive option, irrevocable for a period of five (5) years from the date hereof, to acquire a Petroleum and Natural Gas Lease in the form hereinafter set forth, of all the petroleum, natural gas and related hydrocarbons, except coal (hereinafter referred to as "the leased substances") within, upon or under the lands hereinbefore described, and insofar as the Optionor owns or controls the same all the right, title, estate and interest of the Optionor in and to the leased substances or any of them within, upon or under any lands excepted from, or roadways, lanes or rights-of-way adjoining the lands aforesaid, together with the exclusive right and privilege to explore, drill for, win, take, remove, store and dispose of the leased substances and for the said purposes to drill wells, lay pipe lines and build and install such tanks, stations, structures and roadways as may be necessary.

The option hereby granted shall be open for acceptance at any time within a period of five (5) years from the date hereof, or on or before, but not after, a date thirty (30) days from the date of receipt of notice by the Optionee from the Optionor pursuant to the provisions of Paragraph 19 hereof of the termination, cancellation or expiration of the existing Petroleum and Natural Gas Lease affecting the said lands.

The option may be exercised by the Optionee delivering to the Optionor, or mailing postage prepaid and addressed to the Optionor at the address specified in Paragraph 23 hereof, written notice of its intention to exercise this option accompanied by payment of such amount of lawful money of Canada as shall be necessary to increase the amount paid as consideration for this option to the sum of ... Dollars per acre, which amount shall represent the consideration for the granting of this option and the petroleum and natural gas lease hereinafter set out. The term of the said Petroleum and Natural Gas Lease shall be deemed to commence as of the date of the exercising of the said option (which date is hereinafter referred to as 'the effective date'). ${ }^{\circ}$

This option was subsequently acquired by Scurry-Rainbow Oils Limited and a caveat was registered claiming an interest under the option. In addition to the aforementioned lease, Pan American and Fargo held interests under a lease on the remaining three-quarters of the section of land. Pan American was prepared to drill a well for gas on both of the leases, but well spacing regulations under The Oil and Gas Conservation Act ${ }^{7}$ called for only one well to be drilled on the section. Because of the Gunderson case, ${ }^{8}$ the failure to drill a well on both leases would have resulted in the loss of the lease on which no well was drilled and producing at the end of the primary term of the lease. Consequently, arrangements were made with both of the lessors to pool the two leases to form a spacing unit of one section. With respect to the lease in question, this was accomplished by a letter in the following terms:

\section{Dear Sirs:}

I have been advised that it is your intention to pool the lands comprised in the Petroleum and Natural Gas Lease dated the 16th day of January, A.D. 1951, which you now hold in respect of the ... (160 acres) ... with certain other lands to form a spacing unit comprising ...6640 acres) ...

Please be advised that I consent, as Lessor, to such pooling and in the event that production is obtained in any well drilled on the lands comprised in the spacing unit, agree to accept royalty on the basis set forth in Clause 3 of the said lease, that is the proportion the acreage comprised therein so pooled bears to the total acreage in the spacing unit. In the event that production of natural gas is encountered in any well or wells drilled on the lands comprised in the spacing unit but not on the lands comprised in the said lease, and such production is not sold or used because of unavailability of a market therefor, I agree to accept as royalty the sum of Fifty $(\$ 50.00)$ Dollars or the annual acreage rental in the the said lease reserved, (whichever is the greater amount), each year during the time such production is not sold or used and it shall be deemed that during the time in respect of which payment of such amount is made production is being

$\theta$ This is the relevant portion of the option contained in the "Option and Petroleum and Natural Gas Lease" in the Potapchuic case which is here more fully set out than in the reports of the Potapchule case.

7 1957, c. 63 (Alta.)

$8[1960]$ S.C.R. 424. 
taken from the lands comprised in the said lands and that such payment is received as royalty paid in respect of the said lease. ${ }^{0}$

This letter was prepared to avoid the application of the Gunderson case. ${ }^{10}$ The purpose of the letter was to permit the drilling of only one well on the lands pooled so that if no drilling occurred on the lands in one of the leases that lease would nevertheless be in good standing by substituting the terms of the letter for certain provisions in the shut-in royalty clause of the lease in order that that clause would then deem a shut-in well on the pooled lands to be a producing well under that lease. ${ }^{11}$

Subsequently, and over six months prior to the expiration of the lease in question, Pan American commenced the drilling of a well on the pooled section but not on lands in the lease in question. A little more than one month after the well was commenced, it was completed and capped as a gas well. At all relevant times thereafter the shut-in royalty payments were made to the lessors.

At trial the Plaintiffs, Pan American Petroleum Corporation and Fargo Oils Ltd., posed the following arguments:

(1) Hhat the present case could be distinguished on its facts from the Gunderson case and that the letter amendment avoided the application of the principles of the Gunderson case to the present case.

(2) That the option contained in the Option and Petroleum and Natural Gas Lease offended the Rule against Perpetuities.

(3) That the letter amendment did no more than confer benefits or interests by way of waiver, promissory estoppel or substituted performance. ${ }^{12}$

At trial the Defendant, Scurry-Rainbow, advanced the following arguments:

(1) That by application of the principles of the Gunderson case the Plaintiff's lease had expired at the end of its primary term because of the absence of a producing well on the leased lands at that time.

(2) That the Option and Petroleum and Natural Gas Lease was registered by caveat and took priority over the existing lease insofar as it may have been altered by the letter amendment.

Mr. Justice Cairns disposed of these arguments as follows:

(1) By virtue of the option in the Option and Petroleum and Natural Gas Lease, Scurry-Rainbow acquired an equitable contingent interest in the lands which was subject to the existing lease. By registering a caveat to protect its interest Scurry-Rainbow had prevented, from that date, anyone else taking an interest or bettering or increasing any interest already held in derogation of the interest acquired by Scurry-Rainbow under the option to lease.

(2) The letter amendment was not a mere clarification of what the parties to the existing lease had intended by the shut-in royalty clause in the lease because this clause did not need any clarification beyond what

\footnotetext{
9 As pointed out by Mr. Justice Martland in the Supreme Court of Canada, the letter should have referred to Clause " 9 " and not Clause " 3 ". However, no part of the case [1960] S.C $\mathrm{R}$ point.

10 [1960] S.C.R. 424

11 The effect of the letter on the lease is more fully discussed at p. 288 hereof

Nelther of the Alberta Courts dealt with this argument and it was not made before the Supreme Court of Canada. In respect of it see G. H. L. Fridman, Promissory
} 
the Court said it meant in the Gunderson case. As an amendment to the existing lease, the letter could not affect the vested rights of Scurry-Rainbow under its option to lease.

(3) The option to lease did not offend the Rule against Perpetuities. The Plaintiffs' argument that it was possible for the option to be exercised beyond the perpetuity period in the event that the Plaintiffs' lease continued beyond the primary term and terminated at some indefinite time in the future, failed because under the granting clause in the option, five years was the outside limit for exercise of the option. The true construction of the lease-option provisions was that the period of five years could be shortened by the optionor giving the 30-day notice of termination of the existing lease, but the option could not be exercised after the expiration of five years. Even if this interpretation of the option were wrong, and it was exercisable after five years, the Rule against Perpetuities was not offended because that rule does not apply to cases where an optionor has the right to terminate the option, or at least to do acts which might cause its termination.

On appeal to the Appellate Division of the Supreme Court of Alberta, the same arguments were made, and in affirming the conclusions and reasoning of $\mathrm{Mr}$. Justice Cairns at trial, the Honourable Chief Justice of Alberta gave the following reasons for judgment:

... I find myself in entire agreement with the conclusions and the reasoning of the learned trial judge, Cairns J., (1964) 46 W.W.R. 237, saving that I do not find it necessary to consider the applicability of the decision of the Supreme Court of Canada in Auld v. Scales [1947], S.C.R. 543, reversing 19 M.P.R. 406. My view is that his conclusion is sound, that as the option of the respondents was for an outside period of five years subject to that period being shortened in the manner described by him, the rule against perpetuities cannot apply because the interest of the respondents under the lease which Moser granted the respondent, Potapchuk, the option to acquire, must have vested, if at all, within the period limited by the rule; this conclusion is sufficient to answer and dispose of the appellant's contention that the option offended the rule.

Reduced to its barest essentials, the reasoning of $\mathrm{Mr}$. Justice Cairns in the Potapchuk case gives rise to a single question which must be considered by the parties contemplating an amendment of an existing lease: Will the amendment of any of the provisions of the existing lease create an interest or better or increase any interest already held in the land, legal or equitable, adverse to or in derogation of the claim of a registered encumbrancor intervening between the existing lease and the amendment thereof? In order to answer this question, in each case the parties must consider the nature and effect of the amendment and the interest in the land acquired by the intervening encumbrancor.

It is now quite clear, that an attempt by the lessor to extend the terms of the existing lease or to waive performance of covenants, the non-performance of which would result in the termination, cancellation or expiration of the lease in circumstances similar to or like those in the Potapchuk case will meet with stern resistance from the courts. Until the courts have had an opportunity to develop the case law further it would be pure folly to attempt to predict at what point the courts will allow an amendment to take effect against third parties who have acquired an interest in land prior to the amendment. At this early stage in the development of the case law it can only be said that the Potapchuk case 
reaffirms the proposition that if a lease as amended gives to the lessee more rights than those claimed in the caveat protecting the lease, third parties relying on an intervening caveat are not affected by the amendment. $^{13}$

It is time to examine and evaluate the Potapchuk case and attempt to determine what may be its consequences and influence in directing the course of the law. It is therefore the purpose of this paper to consider some of the problems and possible consequences in amending existing leases after a top lease, an option to lease or other encumbrance has been registered or caveated under the Torrens System of Land Registration in those provinces using such a system. Particular consideration will be given to the nature of options to lease and top leases in general use in Western Canada, the rationale that options to lease create interests in land, the application of the Rule against Perpetuities to option to lease, and the conflicting positions between amendments and rights intervening between an existing lease and its amendment, the overriding effect of the Torrens System of Land Registration, and the form that the amendment must take. Consideration will be given also, to the effect of common forms of amendments, namely, pooling and unitization agreements and orders and royalty trust agreements.

\section{Top Lease and Option to Lease}

Types

In the oil and gas industry the term "top lease"14 is usually used to denote an option to lease petroleum and natural gas substances which have been granted and are held for an uncertain term under an existing lease. It is designed to be exercised at the election of the optionee upon or after termination, cancellation or expiration of the existing lease. Some options to lease, however, are designed to be exercised at any time within a time certain and presumably could be exercised prior to the termination, cancellation or expiration of the existing lease. In such an event, there could be in existence at the same time, two leases of the same substances. So long as the original lease contains an exclusive grant and is properly caveated, no difficulty can be created by the option to lease or top lease. Only if the existing lease has not been caveated or if the grant therein is not exclusive could the question and problems of competing interests arise.

It is possible to characterize and group top leases currently in use, into the following four classes: ${ }^{15}$

13 But see, Canadian Superior Oil of California Ltd. v. Kanstrup and Scurry-Rainbow Ltd. (1963), 39 D.L.R. (2d) 275, 290-91, (Alta. C.A.), where an amendment to an existing lease was upheld as valid against an intervening top lessee who it was held had notice under the caveat of the right acquired under the amendment.

14 In Meyers v. Freeholders Oil Co. Ltd. [1960] S.C.R. 761, 766, Mr. Justice Martland said that: "a toplease is one that takes effect upon the termination of a prior existing lease". This appears to be the only judiclal definition of the term in Canada. In Frankfort Oil Company v. Snakard, 279 F. 2d 436 (1960), 12 Oil and Gas Reporter 901, 911, n. 23, it is stated that: "In the oll and gas vernacular to toplease is to secure a lease on land covered by an existing lease to the end that the toplease will be effective after the expiration of the existing lease and the interest of one or more lessees thereby eliminated. Topleasing has the same insidious characteristics as claim jumping."

15 This classification does not purport to be exhaustive and it is recognized that there may be in existence a number of options to lease which do not fit into the classification set out herein. It is also recognized that a number of such options and others will not fit comfortably into any one of the classes set out but represent two or more of the fit comfortably into any one of the classes set out but represent two or more of the
classes. The purpose of the classification is only for convenience in demonstrating the variety of approaches in draughtsmanship. It is not necessarily suggested that different legal consequences flow from these classes. 
(1) Option to lease within a term certain, or on or before, but not after, a stated period from the date of receipt of notice by the optionee from the optionor of the termination, cancellation or expiration of an existing petroleum and natural gas lease.

The option to lease in the Potapchuk case is typical of this class. A newer form of this class of option, which appears to have been drafted in anticipation of the Potapchuk case, contains an interesting clause in the following words:

the Optionor covenants and agrees with the Optionee that he will not waive any default under, or consent or agree to any modification of, or grant any removal or extension of the term of the said existing Petroleum and Natural Gas Lease.

(2) Option to acquire a petroleum and natural gas lease without reference to an existing lease.

This form of option is quite commonly used in both the presence and absence of existing leases. The following is typical of this class of agreement:

... the Optionor, being the owner of the Petroleum and Natural gas rights in and under the lands herein described, DOES HEREBY GIVE AND GRANT to the optionee the sole and exclusive Option, irrevocable within the time herein limited for acceptance, to lease all the petroleum, natural gas and related hydrocarbons, all other gases, and all other substances (whether fluid or solid and whether similar or dissimilar and whether hydrocarbons or not) produced in association with any of the foregoing or found in any water contained in an oil or gas reservoir, excluding, however, coal and valuable stone, in and under all or any part of the following lands, including the interest of the Optionor in such substances within, upon or under any lands excepted therefrom or roadways, lanes or rights-of-way thereto adjoining.

(3) Agreement for Transfer of one half of Mineral Rights and Option to Lease all Mineral Rights. ${ }^{16}$

This form of Agreement appears to have been quite common in Saskatchewan and gave rise to the Mineral Contracts Alterations Act, 1961.17 The relevant language, typical of this class of Agreement, is as follows: -

DO HEREBY GRANT, assign, transfer and set over unto the said Grantee an undivided one-half interest in all Petroleum, Natural gas and related hydrocarbons within, upon or under the said lands, subject to the terms and conditions of the Petroleum and Natural Gas Lease covering the said lands, and agree to deliver to the Grantee herewith a registerable Transfer of such interest; PROVIDED that notwithstanding such transfer the Grantor shall be entitled to collect and retain for his sole use and benefit the total amount of all future annual delay rentals payable to the Lessor under the terms of the existing lease.

AND the Grantor hereby grants to the Grantee the exclusive option to acquire from the Grantor and the Grantee, in the name of the Grantee or its nominee, a lease of the petroleum and natural gas and related hydrocarbons within, upon or under the said lands. Said option may be exercised by the Grantee at any time within ninety days after receipt of notice in writing from the Grantor that the current lease has been cancelled or has expired, provided said cancellation or expiration shall have occurred within twenty-one years from the date of this Agreement, otherwise said option shall lapse. Said option shall be deemed to be exercised upon the sending by registered mail, postage prepaid, addressed to the Grantor at the address hereinabove set forth, of an executed lease accompanied by a warrant or cheque on one of the Grantee's bankers for the first year's rental payable under the said lease. The said lease shall contain the same terms and conditions as are contained in the current lease, except for the term thereof and the cash rental payable thereunder. The term of said lease shall commence as of a date not earlier than the date of the receipt of notice of the cancellation or expiration of the current lease and not later than the date of the mailing of the executed lease and shall terminate as of the date which shall be ninety-nine years from the date of this Agreement.

16 This class of option is substantially the same as that considered in Prudential Trust Company Limited v. Forseth, [1960] S.C.R. 210, 225-6.

17 1961, c. 79, (Sask.) 
In addition to the share of production to which the Grantee, or its nominee, will become entitled as Lessee under the terms of any lease obtained under the Option, The Grantee shall be entitled to its share of production reserved by the Grantor and the Grantee as Lessors in such lease.

(4) Right of First Refusal.

The relevant language typical of this class of Agreement is as follows:-

DOTH HEREBY grant unto the Grantee the sole and exclusive preferential and prior rights to acquire from the Grantor any interest of the Grantor in the petroleum substances or any of them within, upon or under the said lands or any part or parts thereof, which the Grantor shall desire to dispose of from time to time and at any time during the currency hereof, such rights being granted upon and subject to the following terms and conditions:

1. If at any time during and throughout a period of four (4) years commencing as of the date hereof, the Grantor shall receive or make a bona fide offer acceptable to both him and his offeror and/or his offeree as the case may be, to sell, transfer, lease, license or otherwise in any manner howsoever dispose of any interest in and to the petroleum substances or any of them within, upon or under the said lands or any part or parts thereof, or to renew or extend the term of any estate or interest in the said petroleum substances, whether now or hereafter created, the Grantor shall forthwith advise the Grantee by notice in writing, as hereinafter prescribed, (hereinafter called the 'Grantor's Notice') of all of the terms of such offer, whereupon the Grantee, or its nominee, shall have the first preferential and prior right for a period of thirty (30) consecutive days, (hereinafter called 'the period of first refusal') commencing and including the first day following receipt by the Grantee of such notice, to acquire from the Grantor the interest so intended to be disposed of by the Grantor, as aforesaid, upon and for a consideration Ten (10\%) Percent greater than that disclosed in such offer but otherwise on the same terms and conditions as are contained in the said offer.

It is quite apparent from the four preceding classes of options to lease that the most common method of top leasing is the acquisition of an option to lease. Unknown in Canada are any occurrences involving an option to lease which was exercised prior to the termination, expiration or cancellation of an existing lease or involving a second lease which was granted during the currency of the existing lease. ${ }^{18}$ Therefore, this paper will be devoted primarily to an examination of options to lease petroleum and natural gas which are subject to an existing, valid lease.

The Option to Lease as an

\section{Equitable Contingent Interest in Land}

In the Potapchuk case Mr. Justice Cairns stated that: ${ }^{10}$

Scurry under the option of May 19, 1956, obtained an equitable contingent interest in the land, the contingency being the election to accept the option:

18 However, see the Oklahoma case of Rorex v. Karcher 224 P. 696, 697 (1923), where a top lease was granted during the currency of an existing lease. The Court held that as the lessors were owners of the fee simple estate which was unrestricted "there was no reason why the owners of the fee did not carve out as many estates as they saw fit. There was no reason why the ... (lessors) ... could not execute a second oil and gas lease during the existence of the first lease": "The Court held that in the absence in the existing lease of a covenant to extend the term of the lease during its life, any extension procured was subject to the rights of intervening third persons. An analogous position was taken in the Potapchuk case at p. 243 where Mr. Justice Calrns decided that as an amendment, the letter could not affect the vested interest of Scurry-Rainbow under its caveated option. However, some caution should be exercised in applying this decision in view of the decision of $\mathrm{Mr}$. Justice $\mathrm{K}$ irby in the case of Canadian Superior Oil of California Ltd. v. Kanstrup (1963), 39 D.I.R. (2d) 275, 290-1 (Alta. S.C.), the effect of which is that an amendment of the existing lease is not defeated by a prior registered interest so long as the amendment does not create more rights in the Iands than claimed in the caveat. Conceivably, therefore, if the lessee of the existing lease claimed in its caveat the right, for example, of the lessor to waive any default under. or consent to agree to any modifications of, or renew or extend the term of the existing petroleum and natural gas lease, the optionee or top lessee would take subject to such right and the reasoning of the Potapchuk case would be avoided. An alternative solution to the Potapchule problem might be to include in the existing lease a right in the lessee of first refusal in respect of any bona fide offers made to the lessor by prospective top lessees or other persons seeking to acquire interests in the land.

10 (1964), 46 W.W.R. 237, 242 (Alta. S.C.). 
Frobisher Ltd. v. Can. Pipe Lines \& Petroleums Ltd. [1960] S.C.R. 126, (1957-58) 23 W.W.R. 241 aff., and particularly the reasons of Judson, J. at page 169, where the learned judge states:

'Does an option to purchase land give rise to an equitable interest in land? The question has usually been considered in connection with conveyances and leases and the rule against perpetuities, and it has been held that the option is too remote if it can be exercised beyond the perpetuity period. The underlying theory is that the option to purchase land does create an equitable interest because it is specifically enforceable. There is a right to have the option held open and this is similar to the right that arises when a purchaser under a firm contract may call for a conveyance. In both cases there is an equitable interest but in the case of the option it is a contingent one, the contingency being the election to exercise the option.'

And further at page 171 His Lordship states:

'In the present case, in view of my opinion that Frobisher's attempt to distinguish its position at the first stage of the option from the later stages fails, there is no conclusion possible other than the one that in the period June 25 to June $\mathbf{3 0}$ it did acquire an interest in these claims.'

The significant point made by Mr. Justice Cairns is that the Potapchuk option to lease ${ }^{20}$ created an equitable contingent interest in land, the contingency being the election to accept or exercise the option.

The case of Frobisher Ltd. v. Canadian Pipe lines \& Petroleums Ltd., ${ }^{21}$ on which Mr. Justice Cairns relied, was a 3-2 decision of the Supreme Court of Canada which involved an option to purchase mineral claims as opposed to an option to lease petroleum and natural gas. The question arises whether Mr. Justice Cairns' view of the Potapchuk option to lease is to be considered as laying down a general proposition of law that any option to lease creates an equitable contingent interest in land. In this regard, the words of Mr. Justice Martland seem pertinent: ${ }^{22}$

Reference has been made to the foregoing authorities because they are of assistance in deciding the extent of the judgment of the court of appeal in the Gomm case. It is to be considered as laying down, as a general propostion of law, that any option which relates to land of necessity vests in the optionee, forthwith upon the granting of it, an interest in land? I do not think that it does.

The word 'option' is not a term of art. It does not, by itself, necessarily mean an option to purchase or to call for the whole of the interest of the person giving the option in the subject matter. Its meaning depends upon the context. Its acceptance results in the contract, the nature of which must depend upon the terms of the offer which is made. In each of the cases above cited in which the Gomm case has been followed the offer which was made for valuable consideration was to convey a title to the land to the optionee forthwith upon payment of a stipulated sum of money.

In Canada the Frobisher case is the definitive case on options to purchase land and accordingly important consideration should be given to it. The facts of the Frobisher case, briefly stated, are as follows. On June 25, 1955 the Plaintiff, Frobisher Ltd., through its agent, Harquait, acquired an option to purchase certain mining claims from four prospectors. The option provided that it should remain open until June 30th, 1955 and set out the terms of purchase, including the terms of transfer of the claims on or as close as possible to June 30th whereupon a certain sum would be paid. A further sum was to be paid in stated installments and a new company was to be formed in which the optionors would receive $10 \%$ of the authorized stock. On June 29th the prospectors gave an option to purchase the same claims to the Defendant Company, Canadian Pipe

20 Ante pp. 268-9.

21 [1960] S.C.R. 126; See an interesting comment on the Frobisher case by G. V. La Forest in (1960), 38 Can. Bar Rev. 595.

22 Id., at 162. 
Lines \& Petroleums Ltd., which company not only took with notice of the first option but actively induced the breach of it.

The Plaintiff sued Canadian Pipe Lines \& Petroleums Ltd., certain of its directors, and the four prospectors for specific perfomance of its option and an injunction against any dealings with the claims by the Defendants. A majority of the Supreme Court of Canada, which included Mr. Justices Cartwright, Abbott and Judson, approved the decision of the Court of Appeal in the leading English case of London and South Western Ry. Co. v. Gomm ${ }^{23}$ and held that an option to purchase land vested in the optionee an equitable interest in the lands in respect of which the option was granted. Mr. Justices Locke and Martland dissented. They held that even assuming that an option to purchase land which entitles the optionee to call for a conveyance to himself creates an equitable interest in the optionee, still this doctrine of the Gomm case did not apply to the Frobisher case because the title was to be conveyed not to the optionee but to a company not then incorporated. The initial option given to Harquait did not, in Mr. Justice Martland's words, "confer upon its exercise a right to Frobisher to call for a conveyance of the title to the mineral claims"; therefore, neither Harquait nor his principal, Frobisher Ltd., could acquire an equitable estate or interest in the lands. It was his view that the option merely conferred a right to have a conveyance given to an unincorporated company and that Harquait and Frobisher Ltd. were to acquire only the majority share interest in the company that would be the owner of the claims. The majority of the Court, however, was not impressed by this distinction.

In delivering his opinion, Mr. Justice Judson posed the following question: "Does an option to purchase land give rise to an equitable interest in land?" He answered this question in the affirmative: "The underlying theory is that the option to purchase land does create an equitable interest because it is specifically enforceable."

Mr. Justice Cartwright, who, in affirming the conclusion arrived at by Mr. Justice Judson, stated: ${ }^{25}$

It appears from this ... (which refers to the trial judgment and the injunction by Frobisher Ltd. restraining the defendants from disposing of or 'entering upon, drilling, exploring, developing, operating or otherwise dealing with the mining claims')... that the contract has been construed as conferring upon the appellant not only the right to call for a conveyance of the claims to a company to be incorporated when all the payments stipulated have been made, but also the right during the currency of the option, to the exclusion of all of the respondents to enter upon, drill and explore the mining claims. It is my opinion that on this construction of the contract the appellant, during the currency of the option, could have maintained an action of trespass not only against a stranger who entered on the claim, but also against the respondents if they did not. I find myself quite unable to say that the appellant in these circumstances did not acquire by transfer, assignment or otherwise howsoever, ... any right or interest in the claims'. (Section 9 of the Regulations made under the Saskatchewan Mineral Resources Act). It appears to me that it acquired, by contract, the exclusive right to enter upon, drill and explore the claims during the currency of the option and the right to compel their conveyance upon completion of the option payments. On any reasonable view of the meaning of the words 'right' and 'interest' as used in the regulations I am of the opinion that what the appellant acquired under the contract falls within one or other or both of these words. A very wide meaning ordinarily attributed to both of these words may 
conveniently be found in 'The Dictionary of English Law' by Earl Jowitt at p. 1560 , sub, verb. 'Right' and p. 991, sub, verb. 'Interest,' ${ }^{26}$

What is the effect of the Frobisher case? Three of the five members of the Supreme Court of Canada clearly indicated that it cannot be categorically stated that all options to purchase land create interests in land. Besides the two dissenting Justices, Locke and Martland, Mr. Justice Cartwright of the majority cited a statement from Halsbury's Laws of England to the effect that a contract relating to an equitable interest in property in futuro may, upon its true construction, be a personal contract only. ${ }^{27}$ Yet, the language of Mr. Justice Judson is quite broad and conveys the impression that an option always creates an interest in land because it is specifically enforceable. However, it is unlikely that $\mathbf{M r}$. Justice Judson meant to go this far and thereby disagree with Mr. Justice Cartwright in view of Mr. Justice Abbot's concurrence in both judgments. It would seem therefore that at least four of the members of the Supreme Court of Canada are of the opinion that an option in respect of land may not always create an interest in land.

The primary objection of the dissenting Justices, Locke and Martland, in deciding that the option did not create an equitable interest in land in favour of the optionee, was that the option to purchase did not confer upon the optionee the right to call for a conveyance of the title to the mineral claims. If the option had conferred such a right the dissenting Justices probably would have agreed with the majority of the court that the option to purchase land created an interest in land.

It is submitted that the Frobisher case stands for the proposition that if the option confers upon its exercise a right in the optionee to call for a conveyance of an interest in land it creates an interest in land. There would appear to be no objection to extending the application of this test to an option to lease or, more appropriately, to an option to acquire a profit a prendre. ${ }^{28}$ In the Potapchuk case $\mathbf{M r}$. Justice Cairns applied the principles of the Frobisher case to an option to lease in holding that at the moment the option was granted the optionee acquired an equitable contingent interest in land. Under that particular option to lease, the optionee was given an exclusive option "to acquire a Petroleum and Natural Gas Lease" and it would therefore appear that Mr. Justice Cairns' application of the Frobisher case was justified and proper.

Although Mr. Justice Cartwright found that the option conferred upon Frobisher Ltd. the exclusive right to enter upon, drill and explore the claims during the option ${ }^{29}$ it would appear that the absence in the grant of such rights is not fatal to the acquisition of an interest in land. Such rights were contained in the option to lease in the Potapchuk case but they were worthless because under The Right of Entry Arbitration Act ${ }^{30}$ a specific separate sum must be paid by the lessee for the right of entry

26 Id at 169. It should be observed that the option to purchase the mineral claims did not by its express terms convey these rights, but $\mathbf{M r}$. Justl cCartwright held that such rights were construed by Frobisher Ltd. and the trial court to have been granted in light of Froblsher Ltd.'s obtaining the injunction and in light of the judgment of the trial court. In this regard see the contra-opinion of $\mathrm{Mr}$. Justice Locke at $\mathrm{p}$. 142.

27 [1960] S.C.R. 126 at 139, 147, and 162 .

28 Berkheiser v. Berkheiser [1957] S.C.R. 387 is the leading authority in Canada on what interest is conferred by the usual "unless" type petroleum and natural gas lease, defining it as a profit a prendre terminable upon the happening of any of the contingencies for which it provides.

Which it provides.

30 R.S.A. 1955, c. 290 , s. $12(2)$ 
on, user or taking of the surface of the land. Such sum was not paid in the Potapchuk case.

In the jurisdictions using the Torrens System of Land Registration there are good reasons for treating as an interest in land an option which, when exercised, confers a right upon the optionee to a conveyance of a lease or profit a prendre. Under the various Land Titles Acts in the Western Provinces only documents claiming an interest in land and special statutory documents like mechanics' liens may be registered or protected by registration of a caveat against the title to the land affected. Holding an option to be an interest in land permits the optionee to avail itself of the operation of these Acts, and thus readily to establish priorities between the optionee and persons subsequently acquiring an interest in the lands.

In view of the decision in the Potapchuk case that the option to lease therein considered is an equitable contingent interest in land, the nature of this interest should be more closely examined. Under the four classes of options to lease set forth hereinbefore, the optionee has the right upon exercise of the option to a conveyance to itself of a petroleum and natural gas lease. Normally these options to lease are not exercised until the expiration, termination or cancellation of the existing lease so that at the moment the option is exercised the title of the optioner to the petroleum and natural gas is not encumbered by the original lease and the lease subsequently granted to the optionee is not limited by the rights conveyed under the original lease. However, all but one of the classes of options set forth hereinbefore permit exercise of the option during the currency of the existing lease. In the event that the option is exercised during the currency of the existing lease what interest in the petroleum and natural gas, is acquired by the top lessee?

To determine this question one must enquire into the interest retained by the optionor under the existing lease. Without considering the variety of petroleum and natural gas leases in existence in the Western Provinces, it is sufficient to say that the lessor usually retains a royalty interest in the petroleum and natural gas produced and saved and in the event that drilling is deferred from year to year the lessor receives payment of a "delay rental", so-called, for the privilege of such deferment.

Prior to granting the existing petroleum and natural gas lease the lessor is usually the owner of an estate in fee simple in the mines and minerals in the lands. Upon granting the petroleum and natural gas lease it can be said that the lessor carves out of the fee simple estate an interest which in the usual "unless" type of petroleum and natural gas lease has been held to be a profit a prendre. ${ }^{81}$ After granting the petroleum and natural gas lease the interest held by the lessor may be described as an estate in fee simple subject to the exclusive profit a prendre which he has created and which will be extinguished in accordance with the terms of the grant. It would seem proper, therefore, to characterize the interest that the optionee acquires as an option to acquire a profit a prendre in the future contingent upon the extinguishment of the existing exclusive profit a prendre. When the option is

31 Ante n. 28. 
exercised, the interest of the top lessee is presently vested. If the option is exercised before the extinguishment of the existing exclusive profit a prendre, the interest of the top lessee is presently vested but the use and enjoyment of the grant is postponed until the extinguishment of the existing profit a prendre.

In addition to a contingent equitable interest in land, the optionee acquires certain personal contractual rights by which he can enforce his option to lease. In Prudential Trust Company v. Forseth ${ }^{32}$ Mr. Justice Martland stated that:

Finally, it was contended that, in any event, the provision of the assignment regarding the option to lease was void as offending against the Rule against Perpetuities.

In view of the fact that there are eight producing oil wells on this property, it would seem to me that this issue is really academic, since the option can only be exercised after the termination of the Imperial Oil Limited lease. We are being asked, therefore, to determine questions of law which are unlikely to arise and which, if they arise at all, can only arise in the remote future.

It is sufficient to say that at this stage I would not be prepared to hold that the option is void. The law regarding the subject of contracts relating to rights in the future has been well summarized in Halsbury's Laws of England, 2nd ed., vol. 25, at p. 109, as follows:-

'A contract relating to a right of or equitable interest in property in future may be intended to create a limitation of land only, in which case, if the limitation is to take effect beyond the perpetuity period, the contract is wholly void and unenforceable; or the contract may, upon its true construction, be a personal contract only, in which case the rule does not apply to it; or it may, upon its true construction, be, as regards the original covenantor, both a personal contract and a contract attempting to create a remote limitation, in which case the limitation will be bad for perpetuity, but the personal contract will be enforceable, if the case otherwise admits, against the promisor by specific performance or by damages, or against his personal representatives in damages only. In all cases it is a question of construction whether the contract is intended to create a limitation of property only, or a personal obligation only, or both.'

I am not prepared to say that the assignment did not constitute a personal contract by Forseth, especially when it is borne in mind that the agreement contemplates a future petroleum and natural gas lease to be granted, not by Forseth only, but by both Forseth and Prudential as co-owners. The real effect of his covenant was to give assent to a leasing of his share of the petroleum and natural gas rights along with the share of his co-owner Prudential.

Although not germane to the issues before him, Mr. Justice Martland clearly recognized the contractual and property nature of an option to lease and that insofar as the option purports to create an interest in property, it may offend the Rule against Perpetuities. Nevertheless the optionee may, as against the optionor, enforce the personal covenants in the option, that is, obtain specific performance of the covenant to convey a petroleum and natural gas lease. Therefore, if the optionor makes a disposition of the property to a third party, the only remedy which the optionee has is an action in damages against the optionor for breach of his contractual rights. ${ }^{33}$

In summary, it may be stated that if an option to lease confers upon the optionee a right to call for a conveyance of a petroleum and natural

82 [1960] S.C.R. 210, 225-6.

38 See, Halsbury's Laws of England, vol 23, p. 471, sec. 1090 (3rd ed.); Frobisher Ltd. v.

Can. Pipe Lines \& Petroleums Ltd. [1960] S.C.R. 126, per Mr. Justice Locke at p. 141: ... the right of the optinee. ... is a personal right enforceable in a Court of equity by $a$ decree of specific performance. ." Mr. Justice Cartwright at p. 147 cited the same passage from Halsbury's set forth above as did Mr. Justice Martland in the Forseth case passage from Halsbury's set forth above as did Mr. Justice Martland in the Forseth case against perpetuities altoghther." Per Mr. Justice Martland at p. 163: "An option for the purchase of land creates contractual rights and ... its effect may be to create also a contingent limitation of land which may take effect in the future."; G. V. La Forest (1960), 38 Can. Bar Rev. 595, 599. 
gas lease, the option may be characterized as a contingent equitable interest in land, the contingency being the election to accept or exercise the option. The equitable contingent interest may in most cases, be accurately described as an option to acquire a profit a prendre upon the extinguishment of the existing exclusive profit a prendre. A top lease which is granted during the currency of an existing lease may be said to be presently vested in interest with enjoyment posponed until the termination, cancellation or expiration of the original lease.

\section{The Rule against Perpetuities}

A consideration of the effect of the Rule against Perpetuities on options to lease is necessary because the interest to be acquired upon the exercise of the option may vest beyond the perpetuity period. The classic statement of the Rule against Perpetuities is as follows: ${ }^{34}$

No interest is good unless it must vest, if at all, not later than twenty-one years after some life in being at the creation of the interest.

As pointed out by Morris and Leach, the whole law of perpetuities cannot be reduced to a single sentence but it is surprising how many cases are solved by the foregoing statement of the rule. Nevertheless, in considering the rule, it should be borne in mind that the above is only a general statement and it should also be recognised that the word "vest" is a highly technical term of property law and is used in a peculiar sense in connection with the Rule against Perpetuities.

The period within which interests must vest, if at all, if they are to be valid, is twenty-one years after any reasonable number of lives at the creation of the interest plus actual periods of gestation. Where the interest must vest, if at all, not later than twenty-one years after it is created, there is no necessity for considering "lives in being". An interest is "vested" for purposes of the Rule against Perpetuities when the following conditions exist: ${ }^{85}$

(a) the taker is ascertained, and

(b) any condition precedent attached to the interest is satisfied, and

(c) where any interest is included in a gift to a class, the exact amount or fraction to be taken is determined. This last requirement is peculiar to the Rule against Perpetuities. It is not found in the definition of a "vested interest" for other purposes.

For purposes of discussion of the Rule against Perpetuities in the context of options to lease, only conditions (a) and (b), set forth above, are of interest. It is quite unlikely that circumstances involving class gifts would arise in the context of options to lease and for that reason no consideration is given in this paper to condition (c).

It is not intended to present a full exposition on the subject of vested and contingent interests. The distinctions between the two are so delicate and depend so often upon a minute consideration of the whole language of an instrument that a complete exposition would require a wholly disproportionate amount of space. Consequently, the reader is directed to the numerous text books which contain full and adequate chapters on vesting. It need only be added that the courts have demonstrated a

84 Morris and Leach, The Rule against Perpetuities, 1, (1962 2nd ed.).

35 Id, at 27 . 
strong preference for finding that an interest is vested. This judicial preference is supported in perpetuities cases by the general principle of construction that, if the language of the instrument is ambiguous, a construction that will render the disposition valid is to be preferred to one that would render it invalid. ${ }^{36}$

The Rule against Perpetuities is a doctrine of the law of property, not of the law of contract, and it has been held in England, in the Gomm case $^{37}$ as well as others that an option to purchase land is too remote if it can be exercised beyond the perpetuity period. The reasoning by which this result was reached is as follows. An option to purchase land is specifically enforceable. This gives the option holder an equitable interest in the land, contingent upon his election to exercise the option. Contingent interests in land are void unless they must vest, if at all, within the perpetuity period. Therefore, an option to purchase land which may be exercised beyond the perpetuity period is void to the extent that it creates an interest in land. This reasoning appears to have been approved by way of dicta by the majority of the court in the Frobisher case. $^{38}$

As indicated above, there is no reason to suppose that the Rule against Perpetuities is limited to options to purchase land. The reasons in the Gomm case set forth above for holding that an option to purchase land is subject to the Rule against Perpetuities appears to be equally applicable to an option to lease. However, in the case of a top lease, the rule is not violated since the top lessee is ascertained at the moment the top lease is granted, and no conditions precedent to the vesting of the top lessee's interest must be satisfied. Therefore, the top lessee's interest is vested immediately upon the grant even though its enjoyment may be postponed in perpetuity.

An interesting consideration raised by Morris and Leach ${ }^{39}$ is that, although case authority is lacking, if the option holder is an individual, and the option is construed to be personal to him and not transmissible, it could not be too remote because it would have to be exercised, if at all, within his lifetime. This of course would enable companies wishing to acquire options to lease to avoid the rule by employing individuals to take options, who, upon exercising the option, would transfer the interest acquired to the companies. However, it does not appear that such companies would derive any particular advantage from such an arrangement. But it may well be that an enterprising operator could conceive of a way to utilize this device to avoid the Rule against Perpetuities.

It is well established that if an owner of a present interest can destroy a future interest at his own will and pleasure, that future interest is not invalid by virtue of the Rule against Perpetuities. ${ }^{40}$ The leading case in Canada on this point is Auld v. Scales ${ }^{41}$ which involved a lease of lands for ten years which provided: ${ }^{42}$

... that at the expiration of the ... term ... this demise ... shall at the option of the ... lessee continue as a demise ... from year to year . . . Provided further

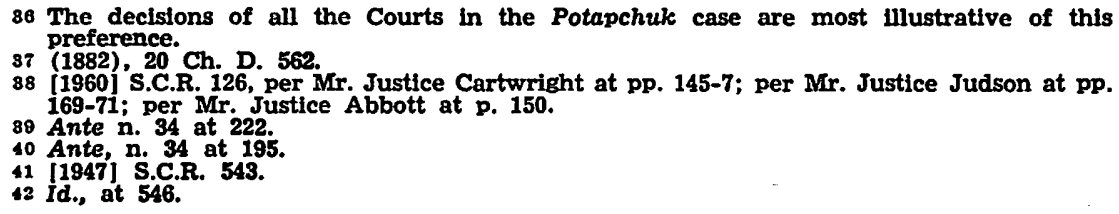


that after the expiration of the ... term . . . lessee shall have the privilege of terminating this lease upon giving to the lessor... notice.

The lease also provided: ${ }^{43}$

$\ldots$ that the lessee shall at all times during the continuance of the . . term or of the continuation thereof have the right, privilege and option of purchasing the ... premises ...

It was contended that the terms of the lease with respect to the option offended the Rule against Perpetuities because the option was to ${ }^{44}$

... enure to the benefit of and be binding upon the parties hereto, their heirs, executors, administrators, and assigns, respectively.

The respondent (lessor-owner) had the power to terminate the lease without the concurrence of his tenant by giving notice in accordance with the relevant law and thereby destroying the option to purchase. The Supreme Court of Canada held that the option to purchase was effective and valid and did not violate the Rule against Perpetuities. Mr. Justice Kellock stated that: ${ }^{15}$

It is said on behalf of the respondent that a tenancy from year to year, unless terminated by notice, is capable of going on indefinitely, and that consequently, as the period of time which was set for the operation of the option here in question was entirely indefinite it is void.

In 'London and South Western Railway Company v. Gomm', . . Jessel M.R. approved of certain passages from Lewis on Perpetuities, one of which is as follows:

'In other words, a perpetuity is a future limitation whether executory or by way of remainder and of either real or personal property, which is not to vest within, the period fixed and prescribed by law for the creation of future estates and interests; and which is not destructible by the persons for the time being entitled to the property subject to the future limitation, except with the concurrence of the individual interested under that limitation.'

Applying the above to the case at bar, it is clear in my opinion that the option to purchase does not offend against the rule.

"The person for the time being entitled to the property subject to the future limitation,'

namely the respondent as owner, may destroy the option by terminating the lease by due notice in accordance with the relevant law without

'the concurrence of the individual interested under that limitation,' namely the appellant or those claiming under him.

Mr. Justice Rand stated that: ${ }^{46}$

... the objection to the option was that as it might be exercised beyond the period of the rule against perpetuities it was void, but to this I cannot assent. The rule is aimed against the tying up of real property pending the vesting of an estate upon a happening which is contingent. But that consideration in policy is absent when the owner of the estate over which the contingent power hovers is able himself at any time to terminate that power. In the classical presentation of the rule by the late Professor Gray the point is suggested that although the lessor in such a case is at liberty, by a proper notice, to destroy the option, it nevertheless involves an onerous condition upon him, namely, that he give up what may be a profitable lease. But if he desires to continue the lease and therefore has no wish either to occupy the land himself or to dispose of it, his only object would be to get rid of an obligation into which he had freely entered, an object which I cannot think can make action to achieve it onerous. With any other object in view, the termination of the lease is a necessary part of its accomplishment.

Mr. Justice Estey stated that: ${ }^{47}$

In Gray on The Rule against Perpetuities, 4th ed., s. 203;

'Thus a future interest if destructible at the mere pleasure of the present owner of the property is not regarded as an interest at all and the rule does not concern itself with it.'

\footnotetext{
43 Ibid.

44 Id., at 549.

45 Id, at 549

10 Id., at 553 .
}

47 Id., at 559 . 
and s. 568 , note 2 :

'When the owner of the present estate can destroy the future interest at his pleasure such future interest is not too remote.'

Auld v. Scales was applied by Mr. Justice Cairns in the Potapchuk case, ${ }^{48}$ where it was contended by the plaintiffs that the option to lease violated the Rule against Perpetuities because the option might vest beyond the perpetuities period. The relevant terms of the option are as follows:

the optionor ... doth ... grant to the optionee the sole and exclusive option irrevocable for a period of five years from the date hereof to acquire a petroleum and natural gas lease ... The option ... shall be open for acceptance at any time within the period of five years from the date hereof, or on or before but not after 30 days from the date of receipt of notice by the optionee from the optionor.

Mr. Justice Cairns held that the option was for five years and was not open for acceptance after that. His Lordship held that the granting clause was clear and that the option clause quoted above, merely provided for the method of accepting the option. Mr. Justice Cairns stated that: 40

I am of the opinion that the right to accept the option does not extend the option past the five-year period, but that the period of five years may be shortened by the optioner giving a 30-day notice of cancellation or default of the Shell lease within which time the optionee has to accept the option rather than wait until the termination of the five-year period. The reason for this probably is that if there is default or cancellation of the Shell lease within the five-year period the optionor can cause the land to be developed by accelerating the time for acceptance of the option.

Having come to the conclusion that the option was for five years subject, as I have stated, to it being shortened, the rule against perpetuities cannot apply because the option must if at all vest within the period limited by the rule.

If, on the other hand, my interpretation of the option is wrong and the time for acceptance extends past the five-year period, the rule against perpetuities does not apply because this rule does not not apply to cases where an optionor, as in the case at bar, has the right to terminate the option, or at least to do acts which might cause its termination: Auld v. Scales [1947] S.C.R. 543 . . .

Two points are of significance. It is implicit in Mr. Justice Cairns' decision that the Rule against Perpetuities applies to options to lease, which, incidentally, are not to be confused with the option to renew a lease which, although in perpetuity, does not offend the Rule against Perpetuities. $^{50}$ It is submitted that when Mr. Justice Cairns stated that the optionor could shorten the time for exercise of the option within the five year period of the option, he failed to consider that a term of the option was that it was irrevocable for a period of five years and that it is repugnant to the concept of irrevocability to permit the optionor to shorten the period. ${ }^{\text {s1 }}$

The other significant point is the extension of the doctrine of Auld v. Scales to the situation where the optionor has the right to terminate the option, "or at least to do acts which might cause its termination".52 It is submitted that Mr. Justice Cairns erred in his application of Auld v. Scales to the option in the Potapchuk case. There, the optionor could give notice to the optionee only upon the termination, cancellation, ex-

48 (1964), 46 W.W.R. 237, 245, (S.C.).

19 Id., at 245 .

51 It is clear from the decision of the Supreme Court of Canada that this argument was not sufficiently persuasive.

62 The Appellate Division of the Supreme Court of Alberta did not find it necessary to comment on the applicability of Auld v. Scales (see, p. 271 of this paper) and in affirmIng the decision of the Appellate Division, it would appear that neither did the Supreme Court of Canada. 
piration or default of or under the existing petroleum and natural gas lease and none of these events were certain to occur. Further, the mere act of giving notice to the optionee did not terminate the lease. Only if the optionee failed to exercise the option within 30 days of such notice did the option come to an end. Therefore, it cannot be said that the optionor could terminate the option to lease at will without the concurrence of the optionee.

As Lewis and Thompson ${ }^{53}$ point out, if the giving of notice by the optionor personally is a condition precedent to the exercise of the option by the optionee, it could be argued that the future limitation did not offend the Rule against Perpetuities because it could not vest beyond the time of a life in being, namely, the life of the optionor.

There appears to be authority ${ }^{54}$ that, as in the Potapchuk case where there was a valid limitation of five years in which to exercise the option, if there is an additional provision in the option which violates the Rule against Perpetuities, that portion which is declared invalid may be severed from the option allowing the valid limitation to stand by itself. This principle was not applied in the Potapchuk case and, apart from Auld v. Scales, it might well have been applied so as to uphold the period of five years and to invalidate the portion which was alleged by the plaintiffs to be offensive to the Rule against Perpetuities. In the Potapchule case, inasmuch as Scurry-Rainbow Oils Limited exercised its option within the five year period in which it had to do so, the option was valid and properly exercised.

The reasoning that the principle of the Gomm case is applicable to options to lease is unassailable if one is willing to ignore the pressures which caused the Rule against Perpetuities to be formulated and the reasons which produced a perpetuity period comprising twenty-one years after lives in being. Excessively long family settlements were the threat which produced the rule and the perpetuity period was designed to fit the needs of family gift transactions. However, to derive from a rule thus motivated and thus formulated a general concept applicable to commercial transactions was a step of dubious wisdom. Lives in being have no significance in commercial transactions, nor has the period of twenty-one years.

Moreover, in accordance with standard perpetuities doctrine, when an option is held to be too remote the entire option is struck down, instead of holding it to be valid for a period of time permitted by the rule. This result is unduly punitive on one party to the advantage of another who may be equally at fault. The usual case involves an option which the optionee attempts to exercise within a very short period. The Rule against Perpetuities is seized upon by the optionor to escape from his contract on the ground that the optionee might have exercised the option too remotely, a situation which does not appeal to the common sense of business men or the ethical sense of anyone. Like the Statute of Frauds, the Rule against Perpetuities becomes a destroyer of bargains which in all conscience ought to be performed. It is encouraging that where, as in the Potapchuk case, the option to lease could have been struck down as violating the Rule against Perpetuities, it was not. 
Some comment should be made in respect of the enforcement of the option against the optionor and his assigns by the optionee or his assigns. Although the law appears to be unsettled in respect of enforcing options to lease, the English law in respect of enforcing options to purchase can be summarized as follows: ${ }^{55}$ If $A$ gives to $B$ an option to purchase land which is unlimited as to time and therefore violates the Rule against Perpetuities, the option can be specifically enforced against $A$ so long as he still owns the land. If $A$ transfers the land to $C$, the option cannot be specifically enforced against $C$, but $B$ is entitled to damages from A or A's estate. It is submitted that no one can be content with this state of the law except $\mathbf{C}$ who discovers, certainly with delight and probably surprise, that he can ignore the option and let someone else pay the damages.

The objection to a long option, from the point of view of the public interest, is that it inhibits the improvement of the land by the owner in possession. This is equally true whether the land is held by the original optionor or by his transferee. There appears to be no justification for refusing specific performance against the optionor's assigns while granting damages against the optionor or his estate, because the well-advised optionor may become overly cautious about transferring land to a transferee who might directly increase the value of the land by improvements and thus increase the liability and damages of the optionor. Something seems amiss when the Rule against Perpetuities actually inhibits the free alienation and development of land.

Perhaps it is an extreme view to suggest that the law should be reformed so that the Rule against Perpetuities does not apply to commercial options of any kind; however, it is a serious matter to strike down a disposition in the name of public policy and it is even more serious to strike down a bargain freely entered into where no threat to the public interest can be shown to exist. An examination ${ }^{58}$ of the cases in which options have been invalidated will reveal a series of episodes in which lawyers have enabled owners to escape from obligations freely assumed; it will reveal few, if any cases in which the performance of these obligations would have caused any detriment to the public. The Potapchuk case is a most recent episode in this series, but one in which the option to lease withstood the assault of the Rule against Perpetuities.

\section{Amendments of Existing Petroleum and Natural Gas Lrase Subject to an Interventng Top Lease or Option to Lease}

Competing Interests and the Effect of McKillop \& Benjafield v. Alexander

Petroleum and natural gas leases usually are granted for a term of ten years and so long thereafter as the leased substances are produced from the leased lands. However, because technological changes and governmental regulations are continually introducing new situations to which the lessee's interest must be adapted, the practice has arisen in the industry of obtaining amendments to existing oil and gas leases to modify existing terms or to introduce new ones. The conflict between amendments of existing leases and prior agreements made between the lessor and third parties is a problem of utmost concern to the oil industry. 
Since the decision of the Supreme Court of Canada in the case of McKillop \& Benjafield v. Alexander ${ }^{57}$ it has long been the view that if a conflict exists between the rights acquired by the lessees under such amendments and the rights of intervening third parties such as optionees and top lessees, such conflict is to be resolved against the lessee if the third parties have taken the precaution of registering or caveating their interests before the amendment is registered or caveated. However, the extent to which the doctrine of the McKillop case is to be applied in circumstances similar to those in the Potapchuk case is uncertain and will continue to be until the doctrine is developed further by the Courts. ${ }^{58}$

Existing petroleum and natural gas leases do not usually contain a provision permitting amendments of the existing lease. The amendments might range from a minor change in the depository named in the lease to which delay rentals and royalties are to be paid to a major change in the primary term of the lease, or it might provide for a waiver or abolition of certain covenants in the lease, which if not complied with would, but for the amendment, result in the termination or expiration of the existing lease. Perhaps the oil industry would do well to consider the possibility of acquiring and caveating such a right of amendment. ${ }^{59}$

Most lessees of petroleum and natural gas register the interest claimed under their leases by way of caveat. ${ }^{.0}$ To avoid the risk of inadvertently omitting to claim under the caveat rights to which the lessee is entitled under the lease, caveats are sometimes registered with the lease attached. In order to avail itself of protection under the Torrens System, the lessee must specify in the caveat with sufficient particularity the nature of the interest claimed. Failure to do so may result in a loss of priority of an interest asserted but not specified in the caveat. The importance of this requirement was emphasized in the case of Ruptash and Lumsden v. Zawick. ${ }^{11}$ There, a caveat which referred to an agreement by date claimed, inter alia, only one of the rights conferred on the caveator by the agreement. It was held that the caveator did not acquire priority under the caveat in respect of any of the rights except that claimed. Mr. Justice Cartwright stated what he considered to be the purpose of registering a caveat: ${ }^{62}$

The purpose of filing a caveat is to give notice of what is claimed by the caveator against the land described. If an unregistered document in fact gives a party thereunto more rights than one in a parcel of land and such party sees fit to file a caveat claiming one only of such rights it appears to me that any person proposing to deal with the land is entitled to assume that the claim expressed is the only one made. Expressio unius est exclusio alterius.

57 (1912), 45 S.C.R. 551.

58 For example, to what extent does registration of a caveat resolve competing equities? Uncertainty is created because of the decisions in Ukrainian Greek Orthodox Church of Canada $\mathrm{y}$. Independent Bnay Abraham Sick Benefit and Free Loan Association, (1959). 29 W.W.R. 97 (Man. C.A.) and St. Mary's Parish Credit Union V. T. M. Ball Lumber Co, [1961] S.C.R. 310. See also, Stephens v. Bannan and Gray, (1913), 5 W.W.R. 201 (Alta. C.A.) and Re Royal Bank of Canada and La Banque d'Hochelaga, (1914), 7 W.W.R. 817 (Alta. C.A.).

59 See ante $\mathrm{n}$. 18 wherein such a provision is suggested. The draughtsman of such a clause must be careful not to make the clause so encompassing that it will be held void for uncertainty or will be found to render other clauses in the lease uncertain and of no effect.

60 See, Land Titles Act, R.S.A. 1955, c. 170, ss. 136-150; Real Property Act, R.S.M. 1954, c. 220, ss. 146-156; Land Titles Act, R.S.S. 1953, c. 108, ss. 138-151.

61 [1956] S.C.R. 347.

02 Id., at 356. 
It is clear from the Ruptash case that in order to acquire priority over a competing interest in land, the interest must be clearly specified in the caveat. Any doubt that may exist that registration of a caveat instead of or in lieu of the instrument which it protects is sufficient protection under the Land Titles Act seems to be resolved by the case of Imperial Oil Limited v. Conroy. ${ }^{63}$ The effect of the Conroy case is that where the lessee of a petroleum and natural gas lease relies upon his lessor's title as a bona fide purchaser for value, the lessee, upon the registration of a caveat prior to any other registration against the lessor's title to the mines and minerals, acquires the interest in oil and gas indefeasibly subject to the exceptions to indefeasibility contained in the Land Titles Acts. ${ }^{64}$ In the Conroy case, $\mathrm{Mr}$. Justice Boyd McBride stated the position to be as follows: ${ }^{85}$

It would be a startling result to hold that because Imperial Oil has chosen to protect its leasehold estate from Conroy by registering a caveat-thereby giving notice to all the world of the interest claimed by it-rather than by registering the lease itself (when, it is conceded by Mrs. Bethiaume's counsel, the registrar would in due course have issued the Imperial Oil a certificate of title to the leasehold estate) that it had thereby deprived itself of the protection otherwise afforded by the Act to any one who, as I have held Imperial Oil did in this matter, deals and acts in good faith, for valuable consideration and in reliance on the title of his author as appearing in the register. This is the general and primary concept underlying our Land Titles Act as is pointed out by Rand, J. in the Turta case, supra, and it is now so clearly established that it cannot in my view be restricted in the manner contended for by counsel for Mrs. Berthiaume. To hold otherwise, in my view, would be an artificial compartmenting of the provisions of The Land Titles Act and would largely destroy the usefulness of its provisions as to caveats above referred to. I cannot agree that the choice made by Imperial Oil to register and rely on a caveat and to leave its lease unregistered was, in the language in the written argument of Mrs. Bethiaume's counsel, a lapse endowed with the seed of death: Alexander v. McKillop and Benjafield (1912), 1 W.W.R. 871, 45 S.C.R. 551, at 553 and 566.

The McKillop case sets out clearly the effect of the registration of caveats: ${ }^{\text {Bo }}$

But whatever its effect as notice, (and I incline to the view that it must be deemed notice to every person who claims to have acquired, subsequently to its being lodged, any interest in the lands, or to have increased or bettered any such interest already held), inasmuch as it is the only means provided for the protection of unregistered interests and it was obviously intended by the legislature thus to afford adequate and sufficient protection for them, I am of the opinion that a caveat when properly lodged prevents the acquisition or the bettering or increasing of any interest in the land, legal or equitable, adverse to or in derogation of the claim of the caveator-at all events, as it exists at the time when the caveat is lodged.

This statement by Mr. Justice Anglin was placed in issue in the Potapchuk case. There the lessee filed the first caveat. The optionee subsequently filed its caveat. The lessee then wished to amend its lease in order to pool land for a spacing unit and to allocate royalty payments dependant upon what proportion the leased acreage bore to the pooled acreage. The critical question posed was whether the amendment created an interest in land or increased or bettered any interest already held by the lessee in derogation of the lessor's grant to the optionee. Mr. Justice Cairns applied the McKillop case to the circumstances before him and held that the option took priority over the amendments to the existing lease. ${ }^{67}$

G3 (1954), 12 W.W.R. (N.S.) 569.

64 See, Lewis and Thompson, Canadian Oll and Gas Law, vol. 1, div. A. sec. 53.

65 Ante n. 63 at 574 .

Bo (1912), 45 S.C.R. 551.

07 (1964); 46 W.W.R. 237, 243. 
The Potapchuk case does not by any means settle the law as to the right of the lessee to amend its lease after the intervention of the interest of a third party. A criticism of the case is that it did not give sufficient attention to the precise nature and effect of the amendment. Only cursory attention was paid to its terms and it appears to have been assumed that the amendment extended the terms of the lease and therefore derogated from the top lessee's grant and increased or bettered the existing lessee's rights. A careful examination of the amendment will indicate that it modified the existing lease as follows: (1) it permitted pooling to form a spacing unit whereas the existing lease only permitted pooling where necessary to conform with governmental regulations or orders; (2) it provided for royalty payments based on the ratio that the leased lands so pooled bore to the total acreage in the spacing unit; (3) it also provided for payment of shut in gas royalty from a well on the spacing unit but not on the leased lands and deemed that such payment be received as royalty paid in respect of the existing lease, whereas the existing lease provided for payment of shut in gas royalty only for wells on the leased lands. The amendment further provided for wells to be drilled on the spacing unit but not on the leased lands. All of the provisions in the amendment were fulfilled. Reduced to its fundamentals, the amendment simply provided for a different method of operation and calculation of royalty than provided for in the lease.

The real question that must be asked is, as regards intervening third persons, in what way did the lessee by its amendment acquire any "interest in the lands" or better or increase "any such interest already held?" In the Potapchuk case the interest acquired by the lessee under the existing lease was a grant of an exclusive profit a prendre which could have been extinguished in accordance with the terms of the grant. It is submitted that the amendment in the Potapchuk case did not confer upon the lessee a new or different "interest in the land" nor did it better or increase "any such interest already held" under the existing lease. The amendment merely changed the mode of performance of certain covenants in the existing lease, giving the lessee the right to pool lands, pay royalties and drill a well on a different basis than provided in the existing lease. It is submitted that the granting of these rights, separately or collectively, was not in derogation of the rights granted to the optionee under its option.

It is contended that the language of Mr. Justice Anglin in the McKillop case $^{68}$ was not directed at freezing the rights of the lessor and lessee under the existing lease in such a manner as to prohibit the modification of certain covenants in the existing lease. It is clear from the decision in the Potapchuk case, however, that modified rights created by amendment will obtain priority only when a new caveat is registered protecting those rights. To what extent the Court will require the registration of a new caveat for each new right acquired is uncertain and will have to wait further development by the Courts.

Another view of the Potapchuk case which heretofore has not been discussed and one which appears to possess much merit is that the issue in the Potapchuk case was not really one of conflict between two parties

68 Ante n. 57. 
claiming priority under the Torrens System, but a case where the lessee under the existing lease was unable to perpetuate its interest because it did not obtain an amendment from the proper party. This view is based on the following reasoning. When the lessor grants a petroleum and natural gas lease, he usually retains a reversion in the estate or interest disposed of under the lease together with the right to royalty payments on production of the leased substances. If, during the currency of the existing lease, the lessor wishes to dispose of his reversion there is usually no objection to his doing so. If the disposition takes the form of an option the optionee usually obtains the right to call for the reversionary estate or interest retained by the lessor. Once he has granted the option the lessor, depending on the nature of the amendment, may be no longer competent to contract with the original lessee in respect of the existing lease. If the option has been exercised the lessor has disposed of all his rights in the reversion and clearly it is the top lessee from whom the original lessee will have to obtain the amendment, however difficult or costly this may prove to be. If the option has not been exercised, it may be that in certain respects the lessor may be competent to amend the existing lease, but the original lessee will be well advised, in any event, to obtain the amendment from both the lessor and the optionee. For example, in the Potapchuk case, the option had been acquired and exercised before the execution of the amendment and had the plaintiffs obtained their amendment from the top lessee it is unlikely they would have suffered any loss. On this view of the law, however misdirected the reasoning of the Courts in the Potapchuk case may have been, there is no doubt that the result of the case is sound.

The consequences flowing from this view may have far reaching effects. The Potapchuk case answered in the negative the question of whether the amendment was effective against a prior registered interest, and it is clear that on the reasoning of the Potapchuk case the caveated amendment would prevail against any interest registered subsequently. If, however, in future cases the courts adopt the view that under the usual top lease the original lessor conveys to the top lessee his entire interest in the reversion and that he is therefore incompetent to amend the existing lease in any respect, it appears clear that the amendment is void ab initio and of no effect against anyone. The only exception to the lessor's inability to amend the existing lease appears to be where the lessor has reserved to himself certain rights, such as the right to royalty and delay rental payments under the existing lease. In such an event it would appear that amendments to the existing lease, such as changes in the depository to which the royalty and delay rental payments are to be made or changes in the address for notice, could be competently dealt with by the original lessor. However, in the Potapchuk case the Plaintiffs sought unsuccessfully to argue that in retaining the right to royalty payments under the existing lease the lessor retained certain rights corollary to the right to royalty payments, namely, to do such acts as might be required, including the execution of an amendment to the existing lease, to realize more quickly and fully the expectation of royalty which, after all, is the real consideration for executing any petroleum and natural gas lease. Such an argument is predicated on the idea that such corollary rights are not disposed of with the reversion; that is, the top lessee has no right or ob- 
ligation to deal with the expectation of royalty reserved to the lessor and, by implication, it is the lessor only who may deal with the original lessee in respect thereof.

There are also practical problems arising from the Potapchuk case. For example, if after the lessor grants an option to lease or top lease, he serves notice upon the original lessee that it is in default of one of its covenants in the lease, such as the covenant to drill an offset well is the original lessee obliged to recognize the notice and to drill the well or suffer termination of the lease? The failure of the lessee to drill the offset well could cause serious drainage of potential production from under the lessor's land and thereby cause a substantial reduction in the amount of royalty due to the lessor. In such an event, it would be essential that the lessor should be able to protect his interest in the expectation of royalty by doing whatever acts are necessary, namely, to insist upon the drilling of the offset well. It would appear that until the option is exercised the lessor could so insist, but after it has been exercised it may be that the lessor who has granted a top lease has no right to compel the original lessee to carry out his covenants and therefore he may not be able to complain of any loss which he has suffered through breach of such covenants. Other problems can be raised to illustrate the point, but they would be better dealt with elsewhere.

\section{Form of Amendments}

It is clear that the option to lease and the petroleum and natural gas lease, no matter how they may be characterized, create interests in land and for purposes of conveyancing, strict attention must be paid to the Imperial Statute of Frauds..$^{\circ 0}$ Often times it is to the advantage of one or both of the parties to obtain an amendment to the terms of the existing agreement and the question arises whether the amendement must be in any particular form. On many occasions it is inconvenient to obtain a formally executed agreement delivered under seal and signed by the parties to be bound. A relatively more simple agreement, like a memorandum or letter agreement, would be equally suitable and more conventiently acquired.

Generally, the form that an amendment should take will depend on whether the agreement to be amended is unenforceable unless evidenced by a written memorandum signed by the parties to be charged, namely, an agreement within the provisions of the Statute of Frauds. ${ }^{70}$

If the agreement is not within the provisions of the Statute of Frauds, then whether it was made under seal, in writing or orally, it may be amended formally or simply by oral agreement. At one time there was a technical rule at common law that an agreement under seal could not be dissolved, either wholly or partially, except by another agreement under seal, ${ }^{71}$ but the Courts of Equity took the opposite view and held that a simple agreement which extinguished or varied the deed was a good defence to an action on the deed. It would appear that this rule of equity

69 (1676) 29 Car. 2, c. 3, s. 4: No action shall be brought . . . upon any contract or sale of lands, tenements or hereditaments, or any interest in or concerning them. unless the agreement upon which such action shall be brought, or some memordanum or note the agreement upon which such action shall be brought, or some memordanum or note
thereof, shall be in writing and signed by the party to be charged therewith or some other person thereunto by him lawfully authorized.

7o See remarks in Cheshire and Fifoot, The Law of Contract, (1964, 6th ed. pp. 468-478).

71 West v. Blakeway (1841), 10 L.J. (C.P.) 173. 
applies in Canada and certainly is applicable in those provinces which have enacted legislation ${ }^{72}$ which provides that in all matters in which there is any conflict or variance between the rules of equity and the rules of common law with reference to the same matter, the rules of equity shall prevail. Cheshire and Fifoot cite the English case of Berry v. Berry ${ }^{73}$ as authority for this proposition. In that case a husband and wife entered into a separation agreement under seal. Subsequently the parties modified the separation agreement by an agreement not under seal. The Court of Kings Bench held that the second agreement was valid and an effective modification of the first. Berry v. Berry was followed in the Alberta case of Pyramid Construction (Calgary) Limited v. Feil and Feil ${ }^{74}$ where Mr. Justice Riley adopted the following summary from Hanbury's Modern Equity: ${ }^{75}$

'Common law would allow the terms of a deed to be varied or dispensed with only by another deed, whereas equity would allow this result to be brought about by a simple contract and would make its ruling effective by preventing the party who had agreed to rescission or variation from suing under the deed. The Act (Judicature Act), as is shown by Berry v. Berry (1929) 2 KB 316, 98 LJKB 748, has had the effect of rendering it always possible to rescind or vary a deed by a subsequent simple contract.'

The rule, that even a written agreement may be modified by a later oral agreement, must not be confused with the parol evidence rule, that parol evidence is inadmissible to contradict, add to or vary a written agreement. The parol evidence rule was designed to prevent the parties from introducing evidence for the purpose of proving that the written contract does not contain all the terms of their agreement. The parol evidence rule is not violated, however, if after the existing agreement has been reduced into writing, the parties thereto enter into an oral agreement, in the words of Mr. Justice Denmon in Goss v. Lord Nugent, ${ }^{78}$

... either altogether to waive, dissolve, or annul the former agreement, or in any manner to add to, or subtract from, or vary or qualify the terms of it, and thus to make a new contract, which is to be proved partly by the written agreement, and partly by the subsequent verbal terms engrafted upon what will be thus left of the written agreement.

If the existing agreement is within the provisions of the Statute of Frauds and the parties thereto desire to amend its terms, their intention must be expressed in a written memorandum signed by the parties to be charged in order to satisfy the formalities of the Statute of Frauds, and if a mere parol amendment is made the original terms of the agreement remain intact and enforceable. The reason for a different rule in respect of amendments to agreements within the Statute of Frauds and those outside of it has been set forth in Morris v. Baron in the judgment of Lord Atkinson: ${ }^{77}$

The foundation, I think, on which that rule rests is that after the agreed variation the contract of the parties is not the original contract which had been reduced into writing, but that contract as varied, that of this latter in its entirety there is no written evidence, and it therefore cannot in its entirety be enforced.

72 See for example the Judicature Act, R.S.A. 1955, c. 164, s, 34 (13).

78 [1929] 2 K.B. 316.

74 (1957), 22 W.W.R. (N.S.) 497 (Atla. S.C.).

75 100, (6th ed.).

76 (1833), 2 L.J. (K.B.) 127, 129.

77 [1918] A.C. 1, 31 . 
Lord Atkinson limited his explanation to cases of variation in the terms of the agreement: ${ }^{78}$

There is a clear distinction, however, between cases such as these and cases ... (where) ... the contract is not varied at all, but the mode and manner of its performance is ... / $/ \overline{\mathrm{M}}$ /oreover recission of a contract, whether written or parol, need not be expressed. It may be implied, and it will be implied, legitimately, where the parties have entered into a new contract entirely or to an extent going to the root of the first inconsistent with it.

It is clear that in Alberta an amendment to an agreement within the Statute of Frauds must satisfy the statutory formalities. In the Pyramid case Mr. Justice Riley adopted the following statement from Cheshire and Fifoot: ${ }^{79}$

The next question is whether the dissolution, either total or partial, of a contract that has been evidenced by writing in accordance wih the Statute of Frauds or the Law of Property Act, 1925, must itself be evidenced by writing. If, for instance, there has been a written contract for the sale of land, and the parties later desire to dissolve it completely, or to substitute a new contract in its place, or to vary its terms, must their intention be expressed in a written and signed memorandum?

The first rule on this matter is that a partial dissolution of the contract is ineffective unless evidenced by a signed memorandum. Any subsequent variation of the written contract must satisfy the statutory formalities, and if a mere parol variation is made the original contract remains intact and enforceable.'

From the foregoing it is clear that because the petroleum and natural gas lease is an instrument falling within the provisions of the Statute of Frauds, any amendment thereto must comply with the statutory formalities. Cheshire and Fifoot sets out the statutory requirements of the contents of the "memorandum or note": ${ }^{\text {so }}$

The agreement itself need not be in writing. A 'note or memorandum' of it is sufficient, provided that it contains all the material terms of the contract. Such facts as the names or adequate identification of the parties, the description of the subject-matter, the nature of the consideration, comprise what may be called the minimum requirements. But the circumstances of each need to be examined to discover if any individual term has been deemed material by the parties; and, if so, it must be included in the memorandum.

Whether or not the requirements of the Statute of Frauds was satisfied was not raised as an issue in the Potapchuk case. It appears without doubt, however, that an amendment in the form of a simple memorandum or letter agreement is satisfactory and would effectively amend a petroleum and natural gas lease.

\section{Pooling and Unitization Orders and Royalty Trust Agreements}

The Potapchuk case has finally established, at least in the circumstances there considered, that any attempt to amend a defective pooling provision in an existing lease will meet with stern resistance from the courts insofar as the amendment may affect the interest of an optionee or top lessee. It appears quite clear that the same result will obtain where, after the optionee, top lessee or other third party has registered its caveat, an existing lease is contributed voluntarily to a pooling or unitization scheme on terms such that the lessor waives or modifies covenants in the lease, the performance of which would, but for the waiver or modification, be necessary to continue the existence of the lease. However, it is quite difficult to anticipate what results the courts may reach in respect of com-

78 Ibld.

79 Law of Contract, 450 (4th ed.).

30 Id at 168. 
pulsory pooling or unitization pursuant to statutory requirements insofar as such pooling or unitization may amend an existing lease and derogate from the rights of optionees and top lessees. It would appear useful therefore to consider the nature and effect of compulsory unitization and pooling orders on the rights acquired by persons having an interest under options to lease, top leases and royalty trust agreements. Brief consideration will be given to how some kinds of royalty trust agreements affect amendments to existing leases.

\section{Amendments by Unitization}

In Western Canada there are in use three methods of effecting unitization: voluntary unitization by agreement, compulsory unitization order ed under statute and a combination of these two. The last leans more to compulsory than to voluntary unitization, but this is not material to this paper. Attention will be given primarily to compulsory unitization effected by order of a provincial tribunal.

\section{Alberta}

In Alberta, with the exception of several units formed and created by special statutes to meet special circumstances at Turner Valley, voluntary unitization is still in vogue ${ }^{81}$ and it is suggested that it is even more voluntary today than it was several years ago. Before its amendment in 1963, section $72(3)$ of the Oil and Gas Conservation Act Arovided $^{82}$ prove that unit operations should not go into effect until the unit agreement had been approved by the Oil and Gas Conservation Board. As a matter of practice, such approval usually involved a public hearing. Pursuant to the 1963 amendment ${ }^{83}$ unit operations may now go into effect after a copy of the unit agreement has been filed with the Oil and Gas Conservation Board.

In the Alberta Act there are also provisions for compulsory unitization ${ }^{84}$ which have not as yet been proclaimed in force by the Lieutenant-Governor in Council. One of these provisions, section 76a, is of particular interest in that it provides that the order for compulsory unitization shall be binding upon each owner of an interest in oil or gas in the unitized area and upon any one entitled to a contractual benefit through an owner. Therefore section 76 a would conceivably bind an optionee or top lessee or other interested third party. Also of particular interest is section 85 which, unlike section $76 \mathrm{a}$, has been proclaimed. It provides that operations carried on under a pooling or unitization order and a portion of the production allocated to a tract shall, for all purposes, be deemed to be within the terms and provisions of each lease or other contract applicable to the unitized or pooled tract.

\section{British Columbia}

In British Columbia voluntary unitization is the only method of unitization available and the new Petroleum and Natural Gas Act ${ }^{88}$ of that Province makes only two brief references to unitization. Section $113(u)$

81 Oil and Gas Conservation Act, 1957, Alta. c. 63, ss. 71 and 72.

82 Ibid.

83 An Act to Amend the Oll and Gas Conservation Act, 1963, c. 42, s 13(c): The words "approved by" were replaced by the words "ffled with".

84 Oil and Gas Conservation Act, 1957, Alta. c. 63, 3s. 75 to 82 and 136(2).

86 Petroleum and Natural Gas Act, $1965 \mathrm{c}$. 33; passed by the British Columbla Legislature on March 22, 1965 and, except for section 155, came into force on May 1, 1965. 
gives the Lieutenant-Governor in Council power to regulate the unitization of a pool or field for the purpose of drilling and producing, and section 138 provides that the Lieutenant-Governor in Council may authorize the Minister of Mines and Petroleum Resources to enter into a unitization agreement on behalf of the Crown and upon its execution the agreement shall be binding on all parties thereto, including the Crown.

\section{Saskatchewan}

In Saskatchewan legislation has been passed to effect compulsory unitization which is brought into effect by Order-in-Council. The Minister of Mineral Resources by virtue of the wide powers granted to him under section 35 to 44 of The Oil and as Conservation Act ${ }^{86}$ may order the Oil and Gas Conservation Board to hold a hearing to consider the need for unitization of a field. If the Board makes certain specific findings in accordance with the Act it may recommend to the Minister that the unit be established, whereupon the Minister will recommend that the LieutenantGovernor in Council order the creation of the unit. Section 43 is of particular interest in that it provides that production from and operations conducted on the unit shall be deemed to be in fulfilment of all the express obligations under the leases in the unit.

\section{Manitoba}

In Manitoba, which has the least oil and possibly the most exhaustive and up-to-date legislation, both voluntary and compulsory methods of unitization are provided for. Voluntary unitization must, however, receive the approval of the Oil and Natural Gas Conservation Board under section 71(2) of the Mines Act. ${ }^{87}$ The Board, by virtue of section 71(3), will not approve voluntary unitization unless the royalty owners of the various tracts to be unitized agree to the unit operation. This is a departure from normal voluntary units where it is not uncommon to have unsigned royalty owners against whom the unit is protected by an indemnity or other provision in the unit agreement. Section 73 also provides for compulsory unitization either upon a motion of the Board itself or upon the application of a working interest owner of a tract that exceeds a spacing unit. The Board then holds a hearing and with the approval of the Lieutenant-Governor in Council may make an unitization order. Section 83 is of particular interest in that it provides that production from and operations conducted on the unit shall be conclusively deemed to be fulfilment of the express or implied obligations under the leases in the unit.

There is no doubt that unitization, whether voluntary or compulsory, has the effect of amending the leases in several major respects. ${ }^{88}$ The most important of these are the extension of the primary terms of such leases beyond their normal expiry dates as a result of the allocation of production from the unit to the various leases, such production being deemed to be production from the leases, and the elimination of the obligation to carry out operations on a particular lease, such operations on any part of the unit being deemed to be operations on each lease. The

86 R.S.S. 1953, c. 327.

87 R.S.M. 1954, c. 166

88 Some of the legal consequences of a unitized lease are set out in Southland Royalty co. v. Humble Oil, 249 S.W. 2d. 914 at 916 (Tex. S.C.), 1 Oll and Gas Reporter, 1431, 1434-5. 
concept of the "one lease", that is, the development of the unitized tracts as if covered by a single lease, is the reason for such provisions. Indeed, all compulsory unitization orders in Saskatchewan and Manitoba contain such provisions and would also in Alberta under the present unproclaimed compulsory unitization sections. An example of such provisions is found in Clause 5 of Part II of O.C. 1719/55 published in The Saskatchewan Gazette of August 19, 1955. Clause 5 provides:

The drilling, completion and operation of a petroleum or natural gas well on any part of the Unit area shall be respectively construed and considered as the drilling, completion and operation of a petroleum or natural gas well on each and every numbered tract and within the terms and provisions of each and every lease and other contract and any and all ratifications, corrections, or other modifications or amendments thereto, covering any portions of the Unit Area, and the production of petroleum or natural gas from any numbered tract shall be considered for all purposes (except the payment of royalties as hereinafter provided) as production of petroleum or natural gas from each and every numbered tract, and within the terms and provisions of each and every lease or other contract covering any portion of the Unit Area and shall continue each such lease and other contract in full force and effect as to all the lands and formations covered thereby, in the same manner and to the same extent as if produced from the land described in and covered by it.

Unit agreements also always contain such provisions which amend the existing leases.

It is patently clear that an agreement for voluntary unitization entered into by a lessee and its lessor has the effect of bettering or increasing that lessee's rights under the existing lease. Thus if a third party has prior to the unit's formation taken and caveated an interest in the leased substances it is quite clear that the lessor would, by agreeing to the unitization scheme, be found to have derogated from his grant to the third party. If there is no actual production from a well on the existing lease which has become subject to the third party's interest or if delay rentals have not been paid, then on the reasoning of the Potapchuk case, the unit agreement insofar as it amended the existing lease would be of no effect as against the third party.

A compulsory unitization order in Saskatchewan and Manitoba, although it derogates from the rights granted by a lessor to third parties, may, as against such third parties, be an effective amendment. While it may be repugnant to some, it appears to be well established that by virtue of its control over "Property and Civil Rights in the Province"89 a provincial government may interfere with the contractual rights of individuals. As authority for this proposition, D. E. Lewis, Q.C.00 cites the case of Tp. of Sandwich East v. Union Natural Gas Co.: ${ }^{91}$

The ... (provincial) ... Legislature has the power to interfere with vested rights so far as property within the Province is concerned, whether these rights be in respect of land or personality, contractual or otherwise.

It is clear that the Provinces of Saskatchewan and Manitoba have exercised their constitutional powers to interfere with the rights of parties to unitize lands on such terms as they alone might decide. Once the compulsory unitization order is made all parties having an interest in the unit are obliged to abide by it. This situation is to be contrasted with voluntary unitization, whereunder the lessor and lessee may refuse to participate in the unitization scheme.

89 The British North America Act, 1867, 30 \& 31 Victoria, c. 3, s. 92 (13)

so Legal Aspects of Unitization in Canada, contained in papers given at the Mines Ministers' Conference of Canada, Lake Louise, Alberta, on September 11, 1956.

01 [1925] 2 D.L.R. 707, 711 (Ont. S.C.). 
In Alberta, Saskatchewan and Manitoba, under compulsory unitization orders, the lease in a unit may have no actual production from a well located on it, but nevertheless it remains in effect under the order beyond its primary term and so long thereafter as production is allocated to it under the terms of the unit order. Although it is not altogether clear, compulsory unitization orders may accomplish by legislation what cannot be accomplished by agreement, namely, increase or better the interest of the lessee and thereby derogate from the rights granted by the lessor to the optionee, top lessee or other third party. Whether or not the optionee, top lessee, or other third party who acquires and caveats its interest prior to the unit's formation is bound by the order is altogether dependent upon and will be determined by the construction placed upon certain provisions of the relevant Acts. ${ }^{22}$ It is submitted that an argument can be made that the effect of these provisions is to bind such parties, but such an argument must be tempered with the experience of the court decisions which demonstrate a reluctance on the part of the courts to allow lessees to perform acts not contemplated by the lease. To effect certainty these statutory provisions should be amended to assure that all persons, whenever their interests are acquired, are bound by the orders.

The defeat of an intervening third party whose aim it is to acquire an advantage possibly to the detriment of an unsuspecting lessor, and definitely to the detriment of the existing lessee, is one advantage, from the industry point of view, that compulsory unitization may provide.

\section{Amendments by Pooling}

Pooling may be accomplished by two methods: voluntary pooling by agreement and compulsory pooling ordered under statute. There can be no doubt after the Potapchuk case, that a pooling agreement which amends an existing lease after that lease has become subject to an option to lease or top lease, will be ineffective, as against the intervening interest created by such option or top lease. The amount of litigation that has occurred in respect of pooling clauses points up the inadequacy and danger inherent in such clauses. The alternative to voluntary pooling may be compulsory pooling which may have the effect of postponing or defeating the interest of an optionee or top lessee who, prior to the compulsory pooling order, acquired an interest in the lands affected by the order. Although the question is of great significance only tentative conclusions may be reached.

For the purposes of this paper it is sufficient to say that "pooling" means the combining of relatively small tracts of land which are subject

92 Section 76a of the Alberta O1l and Gas Conservation Act provides: “. . . the terms and conditions ... (of the unitization order) ... are binding upon each owner of an interest in oll or gas in the field, pool or part thereof subject to the order and upon anyone entitled to a contractual benefit through an owner wan Gas Conservation Act provides: "The portion of init production allocated to a separately owned tract shall for all purposes be deemed to have been actually produced from such tract, and operations conducted pursuant to a unit operation order shall for all purposes be deemed to be operations carried on or conducted for the production of ofl or gas from each separately owned tract in the unit area in the fulfilment of all the express or implled obligations of the owner of such tract or of a producer under each lease and any contract applicable thereto in 80 far as the same relates to the fleld, pool or portion thereof covered by such order."; Section 83 of the Manitoba Mines Act provides: "where ... (a unitization order) ... is made ... the drilling for, or the production of, oil or gas from the unit area, and all operations incidental thereto, carried on by the unit operator shall be conclusively deemed to be carried on or produced by each working interest owner of a tract in the unit area with respect to his tract in fulfillment of all the express or implied obligations of that working interest owner under any lease or contract respecting oil and gas and affecting the tract in so far as that lease or contract affects part of the unit agreement". 
to different leases to form a spacing unit for the purpose of drilling and/or producing a well. In this context pooling is to be distinguished from unitization which contemplates the combining of numerous leases and units of land, sometimes on a pool or field-wide basis. Suffice it to say that, at the risk of oversimplifying a complex subject, the difference between pooling and unitization is one spacing unit.

Compulsory pooling provisions are found in the legislation of each of the four western provinces. ${ }^{93}$ The legislation in Alberta, Saskatchewan and Manitoba has in common a very important feature. In an application for a pooling order the applicant must show that a voluntary pooling agreement cannot, under the Saskatchewan Act, "be effected", or, in the case of the Alberta and Manitoba Acts, be effected on "reasonable" terms. In British Columbia, however, the applicant apparently needs only to demonstrate "the absence of a pooling agreement". The relevant provisions of the four Statutes ${ }^{04}$ are as follows:

\section{Alberto}

Sec. 73 (1) The owner of a tract within a drilling spacing unit may apply to the Board for an order that all tracts within the drilling spacing unit be operated as a unit to permit the drilling for or the production of oil or gas from the drilling spacing unit.

(2) The applicant in his application shall state ...

(a) that an agreement to operate the tracts as a unit cannot be made on reasonable terms,

(c) particulars of the efforts made by him to obtain agreement to the operation as a unit of all tracts within the drilling spacing unit,...

Saskatchewan

Sec. 31 (1) Where two or more separately owned tracts are embraced within a drainage unit, or where there are separately owned interests in all or part of a drainage unit, the owners of such tracts or interests may pool their interests for the development and operation of the unit.

(2) In the absence of voluntary pooling the minister may, upon the application of any interested person, make an order that a hearing be held by the board.

(2a) An application under subsection (2) shall be in writing and shall be accompanied by: ....

(c) A statement setting forth the reasons why voluntary pooling cannot be effected.

\section{Manitoba}

Sec. 65 (1) Where the owners of tracts or interests in a spacing unit ... cannot agree to pool their interests ... a working interest owner of a tract in the spacing unit may apply to the board to order the owners ... to pool their interests...

(2) A person applying for an order under subsection (1) shall state in his application...

(b) that the owners cannot come to a reasonable agreement under Section 64;

(c) what efforts have been made to obtain agreement of the owners under Section 64 together with particulars thereof;

British Columbia

Sec. 88 (2) In the absence of a pooling agreement under subsection (1), an owner who is the holder of a location within or partly within a spacing area may apply to the Chief Commissioner for an order directing the owners who hold locations within or partly within the spacing area to pool those portions of the locations within the spacing area for the purposes of drilling and producing or drilling or producing petroleum and natural gas or either of them from the spacing area.

It should be noted that section 88 of the new British Columbia Act at present only provides for compulsory pooling of Crown leases and does

98 Petroleum and Natural Gas Act, 1965 (B.C.), c. 33.; The Oil and Gas Conservation Act, 1957. (Alta.), c. 63, ss, 73-74. The Oil and Gas Conservation Act, R.S.S. 1953, c. 327, 83. 04 Ibid. 
not provide for compulsory pooling of freehold leases which are extremely rare in northern British Columbia where most of the industry's activity in the province is concentrated. Freehold leases are more commonly encountered elsewhere in the province. Sections $88(1)$ and $88(2)$ of the British Columbia Act, taken together, provide that an owner who is the holder of a "location" within a spacing area may, in the absence of a pooling agreement, apply for a compulsory pooling order. Section 2 of the Act defines "location" as the lands described in "a lease" and the same section defines "lease" as "a valid and subsisting lease issued under this Act". Freehold leases are not issued under the Act and are not therefore covered by it. This was not the intention when the Act was passed earlier this year and an amendment to clarify this point may be forthcoming in 1966. Therefore, further discussion of the Act will proceed on the basis that such amendment has been passed, thereby capturing the intent of the Act.

When a compulsory pooling order is obtained it provides for drilling operations on any part of the pooled lands and such operations are deemed to be on each lease or tract in the pool..$^{95}$ It further provides for the usual allocation of production to each lease or tract in the pool and such production is also deemed to be from each lease or tract in the pool..$^{96}$ Whether or not these deeming provisions are sufficient to bind third parties who acquired their interest prior to the compulsory pooling order is uncertain. It would appear, however, that these provisions are intended to affect only the parties involved in the pooling. As in the case of the unitization provisions ${ }^{27}$ legislative amendments are desirable in order to clarify the various legal implications involved.

There is an apparent omission in the British Columbia and Saskatchewan Acts as to how capped or shut-in wells should be treated for purposes of compulsory pooling. These Acts provide that drilling operations on the pooled lands shall be deemed to be operations on each lease or tract but they do not provide that a well once drilled and capped or shutin is deemed to be a well on each lease or tract so that the lessee can rely on the terms of the shut-in royalty clause of its lease, pay such royalty, and thus continue its lease beyond its primary term. It is submitted that in such an event, on the basis of the decision in the Kanstrup case, ${ }^{08}$ such a lease would be held to have expired at the end of its primary term because of the absence of production from the pooled lands. While compulsory pooling orders in British Columbia and Saskatchewan may amend

95 British Columbia, s. 88 (7) (a) "operations... shall for all purposes be deemed to be carried on or conducted... upon ... separately owned locations ..."; Alberta, s 73(7) (a) "operations... shall for all purposes be deemed to be carried on or conducted 73 (7) upon their ... tracts..."; Saskatchewan s. 34(a) "operations shall for all purposes be deemed to be operations carried on or conducted. . . upon their. poses be deemed to be operations carried on or conducted. . Manitoba, s. 66 (1) "... operations shall be conclusively deemed to be carried on ... with respect to ... (working interest owner's) ... tract in fulfilment of all the express or implied obligations ... under any lease or contract affecting the tract..." See note 93 for the full clation of the various statutes.

06 British Columbia, s. 88(7) (b) "shall be deemed to have been produced by a well on the location ..." Alberta, s. 73(7)(b) "shall be deemed to have been produced from the tract."; Saskatchewan, 8. 34(b) ". production... shall be deemed to have been produced from such tract by a well drilled thereon.": Manitoba, s. 66(2) " " oil or gas or proceeds . . shall be conclusively deemed to have been produced from that tract.". See note 93 for the full citation of the various statutes.

97 Ante, n. 92.

o8 Canadian Superior Oil of Callfornia Ltd. v. Kanstrup and Scurry-Rainbow Oll Ltd., (1964), 47 W.W.R. 129, 147 (Alta. C.A.). 
leases and continue them in force beyond their primary term by virtue of production being deemed to be from the pooled lands, the legislation is clearly inadequate in dealing with the problem of shut-in or capped wells in respect of which no operations are being conducted and from which no production is being taken.

Such is not entirely the case, however, when considering the applicable legislation in Alberta and Manitoba where the statutes in this regard are quite similar. The legislation in these Provinces provides for all that is covered in the British Columbia and Saskatchewan Acts and further provides for the capped and shut-in well situation. In Alberta, section 74 (2) of The Oil and Gas Conservation Act provides that:

Where a well that is capable of production, or that can be made capable of production, has been drilled and is capped or shut in and the well is subject to an order made under subsection (3) of section 73, or subsection (1) of Section 74, the well shall be deemed to be drilled and located on each tract within the drilling spacing unit irrespective of when the future operations are conducted.

The importance of section 74(2) is fully appreciated when one considers that without it, as in Saskatchewan and British Columbia, unless the lessee is producing from or carrying on operations upon the pooled lands, the lease will expire. The lessee will not be able to avail itself of the usual shut-in royalty clause in its lease unless a well is located on that lease or is deemed to be located thereon. Section $74(2)$ avoids this problem and provides that a capped or shut-in well shall be deemed to be drilled and located on the leased lands. Assuming the existing lease has an adequate shut-in royalty provision the lessee may invoke section 74 (2) and its shut-in royalty clause, pay the shut-in royalty and thereby continue its lease in effect.

Section 67 (2) in the Manitoba Mines Act is similar in effect to section 74 (2) of the Alberta Act. However, the Manitoba Act goes further than the Alberta Act and provides that if the existing lease does not contain a shut-in royalty clause such a payment may be provided for in the order:

Sec. 65(4) After hearing the application the Board, with the approval of the Minister, may order ...

Sec. 65(5) ... and the Board may provide in the order...

(h) in respect of each lease of a tract in the spacing unit that does not contain provision for the payment of shut-in or capped well royalties, for the annual payment by the lessee to the lessor of an amount that shall be conclusively deemed to be a royalty and that shall be payable until royalties on actual oil or gas produced on the spacing unit or allocated to the spacing unit . . . become payable.

Sec. 65(7) Where an order made under subsection (4) provides for the matters mentioned in clause $(h)$ of subsection $(5)$, the annual payment by the lessee to the lessor of the amount fixed under the order until royalties on production become payable shall continue the lease in full force and effect as if the amounts so paid were royalties on actual production.

It must be remembered that this rather intriguing provision applies only if one can qualify for an order in the first instance, and only if one has no shut-in royalty clause in the existing lease.

As mentioned earlier, with the single exception of British Columbia, the benefits of compulsory pooling in these provincial statutes are normally only available where the applicant can demonstrate that no voluntary agreement can be reached and this may be difficult to do where a pooling clause is contained in the applicant's lease. In Alberta, for instance, the 
policy of the Oil and Gas Conservation Board has been that if it should appear that there is in existence a pooling agreement, the Board will not interfere because it considers that the validity of the pooling agreement is a matter for the courts to decide. The difficulty in obtaining a judicial interpretation is that time is usually of the essence and the lease could expire before the matter is settled by the court of last resort. An example of this is the Gibbard case. ${ }^{90}$

\section{Amendments by Royalty Trust Agreements}

Royalty trust agreement provisions are various, but generally the lessor assigns to the trustee the royalty, usually $121 / 2 \%$, due to the lessor under the existing petroleum and natural gas lease. The lessor covenants that in the event no lease is in existence when the royalty trust agreement takes effect, he will, in negotiating any new lease or other instrument for cievelopment of his lands, reserve unto the trustee the full $121 / 2 \%$ lessor's royalty subject to the royalty trust agreement.

The trustee normally notifies the existing or new lessee of the royalty trust agreement and registers a caveat protecting the interests acquired under the agreement. These agreements therefore cannot be overlooked by the lessee who wishes to amend its lease. The lessee must treat the trustee the same as an optionee or top lessee. Where the lease is amended by a pooling or unitization agreement the lessee must obtain the consent of the trustee and of the royalty certificate owners, if the trustee does not have full authority under the trust agreement to consent to the unitization or pooling scheme. This is so because the basis for payment of royalties under a pooling or unit royalty agreement is usually different from that under a royalty trust agreement.

If the consent of the trustee to the amendments in question is not obtained the trustee could, apart from any contractual impediment, sustain an action on behald of itself and the royalty certificate owners in the event that less than the royalty reserved in the lease subject to the royalty trust agreement was paid. Such an action is clearly conceivable in the case of payment of royalties pursuant to a unit agreement which could have the result of sacrificing the fair share of allocated substances to one lease for the benefit of an increased share to some other lease controlled by the lessee. In the case of pooling, however, the allocation is usually on an agreed acreage basis and it would be difficult to maintain that such allocation is inequitable. Still, a basic change in the lease royalty is involved, and the trustee might well succeed in its action.

The problems in amending a lease which is subject to a royalty trust agreement are not, from a practical point of view, as serious as in the case of pooling and unitization amendments. The royalty owners' interest is in getting the royalty payment to which they have a contractual right, and they are more apt to be co-operative and agree to the amendments than they are to object to an amendment and continue not to receive any return on their investment. However, lessees should not be-

99 [1961] S.C.R. 725. In particular see the remarks of Mr. Justice Locke at p 731: “ . . it seems to me inconcelvable that the Board would, of its own motion or on the appilcation of either party, direct such pooling when the parties had themselves agreed upon the terms upon which such pooling should be brought about." See also, Voluntary Pooling in Canadian Oil and Gas Law, 1 Alta. Law. Rev. 481 at 493, n. 72 . 
come lethargic and overlook the dangers in failing to obtain the necessary consents.

There are in existence so-called royalty trust agreements which are in reality assignments by the lessor of a percentage of his fee simple mineral title. The problems raised by these agreements in respect of amendments are no different in result than the royalty trust agreements discussed above. These agreements should therefore be dealt with in the same manner. 